\title{
Effect of diethylstilbestrol (DES) and 17 -estradiol (E2) on growth, survival and histological structure of the internal organs in juvenile European catfish Silurus glanis (L.)
}

\author{
Jarosław Król • Wojciech Pobłocki • Tomasz Bockenheimer • \\ Piotr Hliwa
}

Received: 30 January 2013/Accepted: 15 June 2013/Published online: 23 June 2013

(C) The Author(s) 2013. This article is published with open access at Springerlink.com

\begin{abstract}
The effect of supplemented commercial diets with diethylstilbestrol (DES-15, 30 and $60 \mathrm{mg} \mathrm{kg}^{-1}$ ) and $17 \beta$-estradiol (E2-30 and $60 \mathrm{mg} \mathrm{kg}^{-1}$ ), two chemicals commonly used in sex reversal procedure in fish, on survival and growth parameters of juvenile European catfish (Silurus glanis) was evaluated. During the two experiments, lasting 28 days each, fish were kept at temperature $25.2-26.5^{\circ} \mathrm{C}, \mathrm{pH} 7.4-9.3$ and oxygen concentration 5.0-7.3 $\mathrm{mg} \mathrm{O}_{2} \mathrm{dm}^{-3}$. DES supplementation resulted in depressed growth rate of catfish. In experimental groups fed with E2, no negative effect on growth parameters was found. Both chemicals did not result in observed mortality. In all of the experimental DES groups, hepatosomatic index increased significantly, which suggests negative influence on physiological condition of catfish. DES supplementation significantly changed cytological factors of liver cells and caused hepatic alterations in parenchyma, such as vacuolization and blood congestion. Similarly, supplementation of E2 in food resulted in changes in cytological parameters of hepatocytes. However, E2 did not cause pathological changes within the liver tissue. Histological examination of the catfish gonads showed 19 and $38 \%$ of sterile fish after treatment with 30 and $60 \mathrm{mg} \mathrm{kg}^{-1}$ of DES, respectively. The results suggest that DES served in food could be ineffective in hormonal feminization process of European catfish. No disturbances of sex differentiation process after E2 treatment were observed. However, slight feminization effect in the highest level of E2 treatment group was recorded.
\end{abstract}

Keywords European catfish · Feminization · Growth · Histological structure . Internal organs

J. Król $(\bowtie)$ · W. Pobłocki · T. Bockenheimer · P. Hliwa

Department of Ichthyology, University of Warmia and Mazury, Olsztyn, Poland

e-mail: krolas@uwm.edu.pl 


\section{Introduction}

The European catfish Silurus glanis has been cultivated in ponds in Central and Eastern Europe for more than 100 years. The fast growth, lack of scales and good nutritional value of the fillets containing a small amount (6-8 \%) of fat (Fauconneau and Laroche 1996) have contributed to increase in interest in aquaculture of this species in recent years (Linhart et al. 2002).

In European catfish, sexual growth dimorphism was confirmed. Males grow generally faster and reach a larger size than females (Haffray et al. 1998). The main advantage in production of monosex stocks in aquaculture depends on which sex displays marked growth superiority (Beardmore et al. 2001). In case of female homogametic species (XY), such as in European catfish, production of all male population could be obtained in two ways: by direct method-androgenesis or with estrogens for the indirect masculinization. In the latter case, sexually undifferentiated fish are treated with estrogens to produce heterogametic (XY) neofemales. In the next generations, these neofemales are crossed with normal males, and in the next step, as supermales (YY) they are crossed with normal females (XX) (Piferrer 2001). This work is only focused on the first step of indirect masculinization procedure-production of European catfish neofemales.

Usually, for effective sex reversal in fish, sex steroids should be given before the gonadal differentiation period and should be continued until the sex differentiation takes place (Piferrer 2001). Dietary treatment and immersion are the most acceptable methods of administration of the steroids. Both methods for sex reversal feminization of fish have been shown to be effective for Cyprinidae, Percidae, Ictaluridae, Salmonidae and Cichlidae (Pandian and Sheela 1995). DES and E2 are chemicals commonly used in sex reversal procedure in fish. High feminization effect after E2 or DES treatments in common carp Cyprinus carpio (Basavaraja et al. 1997), Mozambique tilapia Oreochromis mossambicus (Rosenstain and Hulata 1994) and Siamese fighting fish Betta splendens (Kavumpurath and Pandian 1993) was observed. In case of catfishes, which have commercial importance in world aquaculture, feminization success in African catfish Clarias gariepinus (Hossain et al. 2002) and stinging catfish Heteropneustes fossilis (Haniffa et al. 2004) was confirmed.

Data on survival and growth of hormonally sex-reversed fish are important information on achievement of hormonal induction of sex reversal. E2 has been reported to affect survival negatively in many fish species such as chinook salmon Oncorhynchus tshawytscha (Hunter et al. 1986), zebra cichlid Cichlasoma nigrofasciatum (George and Pandian 1996) and mud loach Misgurnus mizolepis (Kim et al. 1997). Some chemicals, used in sex reversal procedure, affected growth rate of the treated fish. Contrary to androgens, estrogens more often influenced the growth of examined fish negatively. E2 and DES have been proven to depress growth in many fish species, i.e., halibut Hippoglossus hippoglossus (Hendry et al. 2003), channel catfish (Gannam and Lovell 1991), char Salvelinus fontinalis (Johnstone et al. 1979), rainbow trout Oncorhynchus mykiss (Matty and Cheema 1978) and sunshine bass Morone chrysops $\times$ Morone saxatilis (Davies and Ludwig 2003). On the other hand, E2 in yellow perch Perca flavescens (Malison et al. 1988) and DES in plaice Pleuronectes platessa (Cowey et al. 1973) or in common carp (Basavaraja et al. 1989) promoted somatic growth. Previously, also negative effects of estrogen have been reported on the metabolism and the functioning of the liver in fish (Haux and Norberg 1985; Washburn et al. 1993; Shved et al. 2007).

The aims of these studies were to determine the effect of commercial feed supplemented with DES or E2 on survival and growth parameters of European catfish juveniles. Finally, 
cytological and histological indicators of the liver and the effectiveness of both chemicals for sex reversal feminization in catfish were verified.

\section{Materials and methods}

Fish and experimental design

The experimental protocols and data analyses were the same for both experiments. In both cases, 4-week-old juvenile European catfish were used. The initial weight of the fish used in both experiments varied (Table 1), because the temperature of rearing both groups of catfishes before the experimental periods was different. Both experiments began after 2 days of acclimation period and lasted 28 days. In Experiment 1, fish were randomly divided into four groups and fed on commercial diets without DES (0 DES - control group) or with DES (15 mg kg${ }^{-1}-15$ DES group; $30 \mathrm{mg} \mathrm{kg}^{-1}-30 \mathrm{DES}$ group; and $60 \mathrm{mg} \mathrm{kg}^{-1}$-60 DES group). In Experiment 2, three different groups were set: without E2 (0 E2 - control group) and with E2 $\left(30 \mathrm{mg} \mathrm{kg}^{-1}\right.$-30 E2 group and $60 \mathrm{mg} \mathrm{kg}^{-1}$-60 E2 group) in diets. All the groups were set in duplicate. Diets were supplemented by DES or E2 using vacuum chamber (AGA Labor, Lublin, Poland). The fish were fed four times a day (9:00, 12:00, 15:00 and 18:00). During the first 2 weeks of the study, the feed ration was equal to $5 \%$ of the fish biomass. In the last 2 weeks of the study, this ration was reduced to $2 \%$ of the fish biomass. Catfish (50 individuals per tank) were reared in tanks with a volume of $60 \mathrm{dm}^{3}$ each, set in recirculating system. Temperature, $\mathrm{pH}$ and oxygen concentration in both experiments were similar and ranged $25.2-26.5{ }^{\circ} \mathrm{C}, 7.4-9.3$ and 5.0-7.3 $\mathrm{mg} \mathrm{O}_{2} \mathrm{dm}^{-3}$, respectively. The photoperiod applied was $0 \mathrm{~L} / 24 \mathrm{D}$.

Data collection, analysis and statistics

All the fish from each tank were individually weighed on day 0 , before starting the experiments. Intermediate weight measurements (15 fish in each tank) were taken weekly. Specific growth rate $\left[\operatorname{SGR}\left(\%\right.\right.$ day $\left.^{-1}\right)=100\left(\mathrm{LnW}_{2}-\mathrm{LnW}_{1}\right) t^{-1}$ where $\mathrm{W}_{1,2}=$ average wet body mass $(\mathrm{g})$ and $t=$ time interval between weight control day] was calculated for each week of rearing. The total SGR was calculated for the whole experimental period.

At the end of both experiments, all fish from each tank were individually weighed. For histological examination, livers from ten fish (from each experimental group) and gonads from twenty fish (from each tank) were collected. After dissection, the livers were weighed and hepatosomatic index [HSI $(\%)=100$ (liver weight body weight ${ }^{-1}$ )] was determined. The tissues were fixed in Bouin's fluid, dehydrated in ethanol, cleared in xylene, embedded in paraffin blocks, sliced into 5- $\mu \mathrm{m}$ sections with a Leica RM 2255 rotary microtome (Leica, Germany) and stained with hematoxylin and eosin (H\&E). Histological analysis was performed and measurements were taken with a light microscope DM 3000 (Leica, Germany) with Qwin 3.0v (Leica, Germany) software. For cytological characterization of the liver, the diameter of 50 hepatocytes and their nuclei from each specimen was measured. The number of hepatocytes was established from 30 fields $\left(1,000 \mu^{2}\right.$ surface area) from each fish also. The nomenclature of germ cells and cellular structures of the gonads was used according to Hliwa et al. (2003) and Schulz et al. (2010).

The data were analyzed using one-way ANOVA. Normality of parameter distribution was tested by Kolmogorov-Smirnov test. The data expressed in percentages were arcsin- 


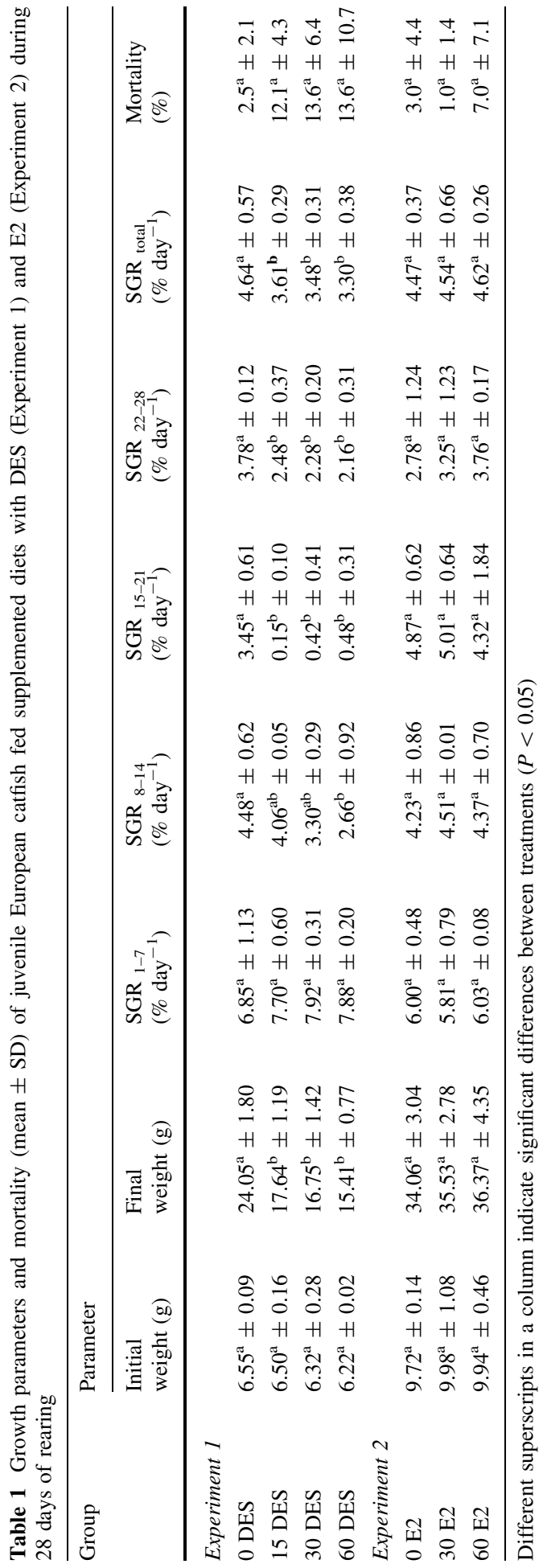


transformed prior to statistical analysis. Differences between groups were estimated using a post hoc Duncan's multiple-range test with a significance level at $P<0.05$.

\section{Results}

Growth performance

At the end of Experiment 1, significantly lower fish body weight in all experimental groups was recorded (Table 1). Additionally, individuals treated with DES had abnormally enlarged ventral part of the body. First differences in growth rate emerged in the period from 8 to 14 days of the Experiment 1, when the fish fed with the highest dose of DES had significantly lower $\mathrm{SGR}_{8-14}$ in relation to the other groups (Table 1). The dramatic depression of the growth rate $\left(\mathrm{SGR}_{15-21}\right)$ in all groups of fish treated with DES, independently of hormone dose, was observed in the following week (Table 1). During Experiment 2, the diet with E2 did not have a significant impact on either body weight or growth rate (Table 1). There were no significant differences in mortality between all the treatment and the control groups (Table 1).

Histological study

In all fish fed with DES and E2, HSI increased significantly (Table 2). Especially in fish fed on diets with DES, this parameter was almost three times higher than in control group. DES supplementation significantly changed cytological factors of liver cells, characterized by bigger diameter of hepatocytes and their nuclei and significant lower number of these cells in liver tissue (Table 2). DES also caused some hepatic alterations in parenchyma, such as vacuolization and blood congestion (Fig. 1). Similarly, supplementation of E2 in food resulted in some changes in cytological parameters of hepatocytes (Table 2). However, E2 did not cause pathological changes within the liver tissue.

Table 2 HSI and cytological indicators of the liver (mean \pm SD) of juvenile European catfish fed supplemented diets with DES (Experiment 1) and E2 (Experiment 2) after 28 days of rearing

\begin{tabular}{|c|c|c|c|c|c|}
\hline \multirow[t]{2}{*}{ Group } & \multicolumn{5}{|l|}{ Parameter } \\
\hline & HSI (\%) & $\mathrm{H}(\mu \mathrm{m})$ & $\mathrm{HN}(\mu \mathrm{m})$ & $\mathrm{HN} / \mathrm{H}$ & Number of $\mathrm{H}$ \\
\hline \multicolumn{6}{|c|}{ Experiment 1} \\
\hline 0 DES & $3.41^{\mathrm{a}} \pm 0.28$ & $14.73^{\mathrm{a}} \pm 2.61$ & $3.97^{\mathrm{a}} \pm 0.61$ & $0.28^{\mathrm{a}} \pm 0.06$ & $3.39^{\mathrm{a}} \pm 0.58$ \\
\hline $15 \mathrm{DES}$ & $7.22^{\mathrm{b}} \pm 0.92$ & $16.67^{b} \pm 2.93$ & $4.71^{b} \pm 0.77$ & $0.29^{\mathrm{a}} \pm 0.07$ & $2.12^{b} \pm 0.38$ \\
\hline $30 \mathrm{DES}$ & $7.20^{\mathrm{b}} \pm 0.07$ & $17.40^{\mathrm{b}} \pm 2.94$ & $4.64^{b} \pm 0.71$ & $0.27^{\mathrm{a}} \pm 0.06$ & $2.08^{b} \pm 0.52$ \\
\hline $60 \mathrm{DES}$ & $8.49^{b} \pm 0.19$ & $16.72^{\mathrm{b}} \pm 1.87$ & $4.86^{\mathrm{b}} \pm 0.72$ & $0.29^{\mathrm{a}} \pm 0.05$ & $2.00^{\mathrm{b}} \pm 0.37$ \\
\hline \multicolumn{6}{|c|}{ Experiment 2} \\
\hline $0 \mathrm{E} 2$ & $1.91^{\mathrm{a}} \pm 0.11$ & $13.87^{\mathrm{a}} \pm 2.05$ & $3.74^{\mathrm{a}} \pm 0.56$ & $0.27^{\mathrm{a}} \pm 0.05$ & $3.75^{\mathrm{a}} \pm 0.46$ \\
\hline $30 \mathrm{E} 2$ & $2.26^{\mathrm{b}} \pm 0.01$ & $15.36^{\mathrm{b}} \pm 2.67$ & $3.86^{\mathrm{a}} \pm 0.51$ & $0.26^{\mathrm{a}} \pm 0.05$ & $3.82^{\mathrm{a}} \pm 0.58$ \\
\hline $60 \mathrm{E} 2$ & $2.42^{\mathrm{b}} \pm 0.04$ & $15.58^{\mathrm{b}} \pm 2.26$ & $4.00^{\mathrm{b}} \pm 0.59$ & $0.26^{\mathrm{a}} \pm 0.04$ & $2.93^{\mathrm{b}} \pm 0.58$ \\
\hline
\end{tabular}

Different superscripts in a column indicate significant differences between treatments $(P<0.05)$. H sizediameter of hepatocyte; HN size-diameter of hepatocyte's nucleus; HN/H—nucleus/cytoplasm diameter ratio; number of $\mathrm{H}-$ number of hepatocytes for $1,000 \mu \mathrm{m}^{2}$ of liver tissue 

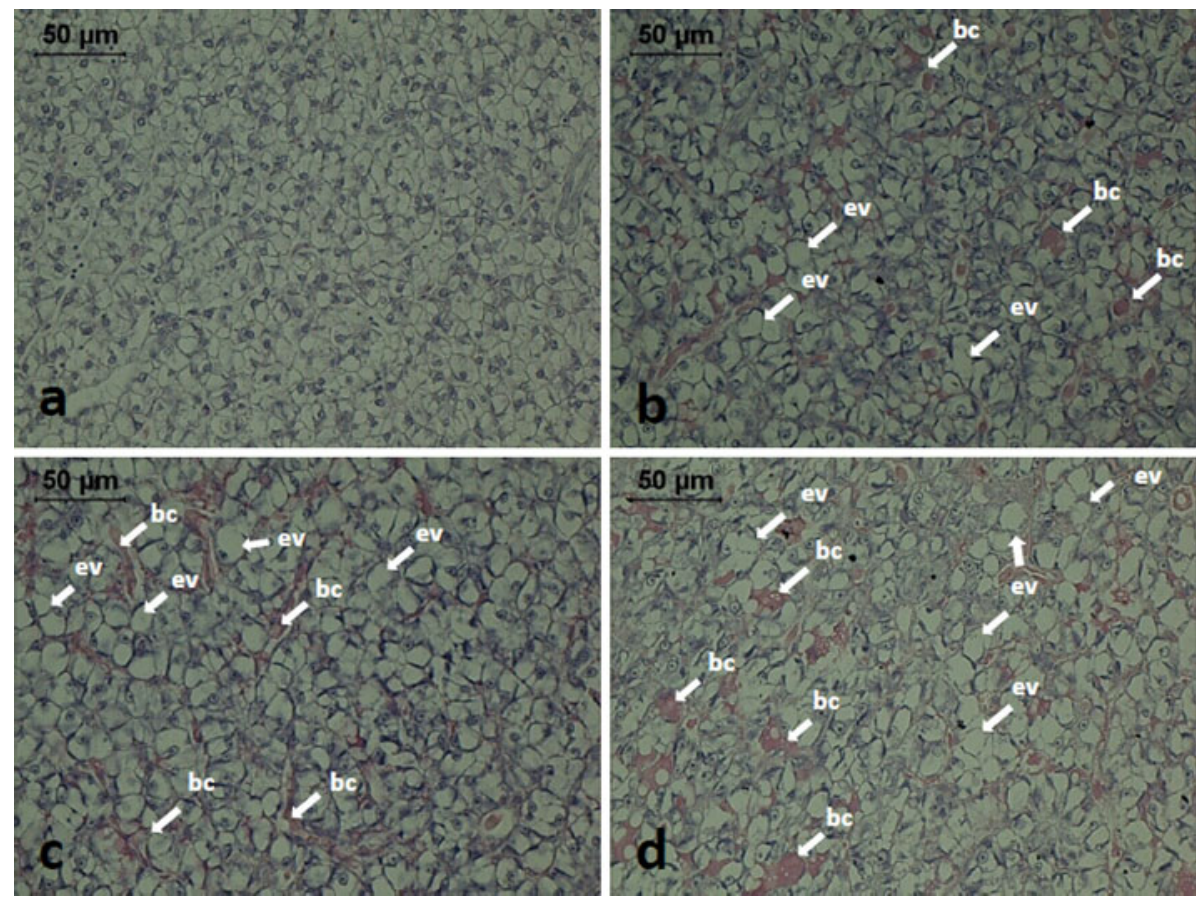

Fig. 1 Cross section of the liver of juvenile European catfish fed supplemented diets with DES after 28 days of rearing. a 0 DES; b 15 DES; c 30 DES; d 60 DES. Description: $b c$ blood congestion, $e v$ extracellular vacuolization

Development of the gonads in the control groups was typical for ongoing oogenesis and spermatogenesis in females and males, respectively. At the end of both experiments, the ovaries were characterized by a medially located ovocell and contained oogonia and previtellogenic oocytes. Males had relatively smaller lobate gonads containing spermatogonia. However, sex ratio of fish in both control groups was different from expected 1:1 (Fig. 2). Ovaries and testes of females and males, respectively, in control and all treatment groups did not differ one from another in the developmental stage and the size (Fig. 3a, b). After treatment of E2, slight feminization effect was observed. In groups 30 E2 and 60 E2, 54 and $69 \%$ of females were found, respectively (Fig. 2). Contrary to results obtained from Experiment 2, in group 15 DES, $71 \%$ of males were recorded. Moreover, after treatment with 30 and $60 \mathrm{mg} \mathrm{kg}^{-1}$ of DES, 19 and $38 \%$ of sterile fish were observed, respectively (Fig. 2). Sterile fish were characterized by various shapes of gonads without any germ cells (Fig. 3c, d).

\section{Discussion}

Some chemicals, used in sex reversal procedure, affected growth rate of the treated fish. In some fish species, estrogens or androgens induce different patterns of growth hormonereleasing hormone (GHRH) and somatostatin-releasing inhibitory factor (SRIF); furthermore, one may mediate different effects on both hypothalamic neurons, including the appetite control centers (Hassan et al. 2001; Cardenas et al. 2003). Estrogens usually 


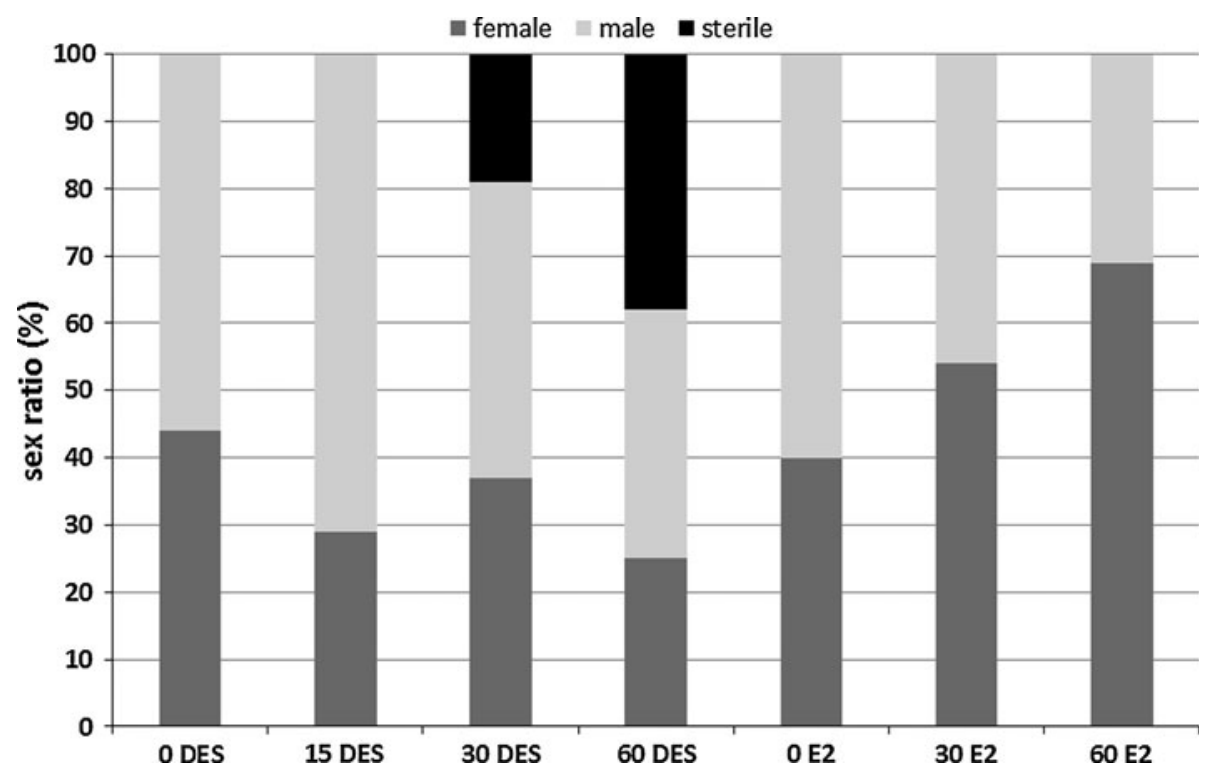

Fig. 2 Sex ratio of juvenile European catfish fed supplemented diets with DES (Experiment 1) and E2 (Experiment 2) during 28 days of rearing
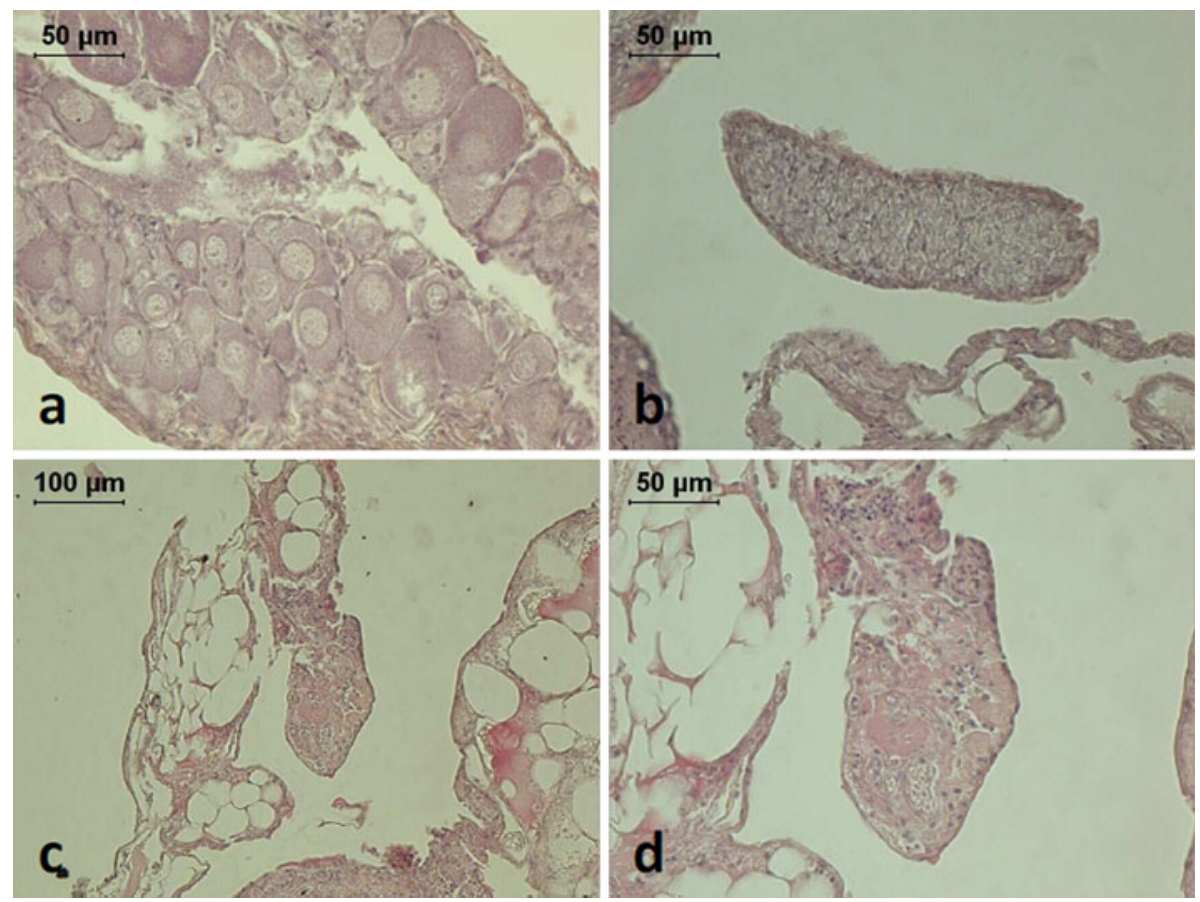

Fig. 3 Cross section of the gonads of juvenile European catfish fed supplemented diets with $60 \mathrm{mg} \mathrm{kg}^{-1}$ of DES after 28 days of rearing. a ovaries; $\mathbf{b}$ testis; $\mathbf{c}, \mathbf{d}$ sterile gonads 
affected the growth of treated fish negatively. For example, E2 and DES depressed growth in halibut (Hendry et al. 2003), channel catfish (Gannam and Lovell 1991), char (Johnstone et al. 1979), rainbow trout (Matty and Cheema 1978) and sunshine bass (Davies and Ludwig 2003). However, E2 in yellow perch (Malison et al. 1988) and DES in plaice (Cowey et al. 1973) or in common carp (Basavaraja et al. 1989) promoted growth by stimulating appetite. In our studies, DES supplementation resulted in depressed growth rate, while in experimental groups fed with E2, nonnegative effects on growth parameters were found. Exposure of Nile tilapia Oreochromis niloticus fry to estrogen had long-lasting effect on the production of insulin-like growth factor I (IGF-I). IGF-I, produced mainly in the liver, is under control of the growth hormone $(\mathrm{GH})$ and plays a central role in the complex system that regulates growth (Shved et al. 2007). A similar mechanism of changes associated with the growth rate of the European catfish fed with DES could be present in our study.

Some negative effects of estrogens on metabolism and the disturbance of the function of the liver in fish have been documented (Haux and Norberg 1985; Washburn et al. 1993; Shved et al. 2007). Perhaps, these changes remain in relation to exhaustion subsequent to enhanced liver metabolism, since it is well known that exposure to estrogenic compounds induces vitellogenin (Vtg) production, which enlarges the liver (Verslycke et al. 2002). Exposure of rainbow trout to E2 revealed significant alterations in the liver tissues, i.e., decrease in glycogen levels and protein concentration and an increase in hepatic lipids, especially triglycerides (Cakmak et al. 2006). In all groups of catfish fed with DES, HSI increased significantly, which suggests negative influence on physiological condition of fish. Treatments of exogenous estrogen in rainbow trout (van Bohemen et al. 1982) and Nile tilapia (Shved et al. 2007) showed a similar increase in HSI and histopathological changes in the liver tissue. In our study, DES supplementation also significantly changed cytological factors of liver cells characterized by bigger diameter of hepatocytes and their nuclei and significant lower number of these cells in liver tissue. Cytological changes related to both the number of liver cells and the size of hepatocytes and their nuclei suggest that DES influenced not only at the cytoplasm of hepatocytes level but also in terms of their nuclei. DES also caused some hepatic alterations in parenchyma like vacuolization of hepatocytes. Similarly, supplementation of E2 in food resulted in some changes in cytological parameters of hepatocytes. However, E2 did not cause pathological changes within the liver tissue.

E2 has been reported to affect survival negatively in many fish species such as chinook salmon (Hunter et al. 1986), zebra cichlid (George and Pandian 1996) and mud loach (Kim et al. 1997). In our study, both chemicals did not result in observed mortality.

Sex reversal to female direction is more difficult than masculinization process. The effectiveness of DES and E2 to feminize may be dependent on the species and the management conditions. Hopkins et al. (1979) used diet with $100 \mathrm{mg} \mathrm{DES} \mathrm{kg}^{-1}$ for 5 weeks to produce $64 \%$ females of blue tilapia Oreochromis aureus. Rosenstain and Hulata (1994) obtained 98 and $100 \%$ of females in two sets of the same species that were fed on diet with $100 \mathrm{mg}$ DES $\mathrm{kg}^{-1}$ for 30 days. Using E2 was successful in halibut (Hendry et al. 2003), European eel Anguilla anguilla (Tzchori et al. 2004) and shortnose sturgeon Acipenser brevirostrum (Flynn and Benfey 2007). In our studies, ovaries and testes of females and males, respectively, did not differ in the developmental stage and the size between control and all treatment groups. After treatment with E2, slight feminization effect was observed. Contrary to that, results obtained from Experiment 1 suggest that DES served in food could be ineffective in hormonal feminization process in European catfish. This state was confirmed by histological examination of the gonads, where after DES treatment more 
males or sterile fish were observed. The gonads of sterile European catfish were characterized by various shapes with different somatic cells without any germ cells. Estrogens have been reported to cause gonadal damage, rendering the fish sterile (Yang et al. 2008). There are only a few reports that documented sterilization after treatment with compounds that have estrogenic activity, and appearance of hermaphrodites or intersex fish is often observed after treatment with estrogens (Piferrer 2001). Nevertheless, sterilization can occur after long exposure to the natural estrogen, as it has been reported in the sea bass, Dicentrarchus labrax (Blazquez et al. 1998). In our study, no changes in sex differentiation process after E2 treatment were observed. Our results obtained from E2 treatment did not exclude usefulness of this estrogen for direct feminization in European catfish, i.e., through using higher doses or long-lasting treatment.

Open Access This article is distributed under the terms of the Creative Commons Attribution License which permits any use, distribution, and reproduction in any medium, provided the original author(s) and the source are credited.

\section{References}

Basavaraja N, Nandeesha MC, Varghese TJ (1989) Effects of feeding diethylstilbestrol on the growth, body composition and organoleptic quality of the common carp, Cyprinus carpio (L.). Indian J Anim Sci 59:757-762

Basavaraja N, Gangadhar B, Udupa KS (1997) Effect of diethylstilbestrol-incorporated diet on sex ratio and body composition of common carp, Cyprinus carpio. J Aquac Trop (Calcutta) 12:209-218

Beardmore JA, Mairg GC, Lewis RI (2001) Monosex male production in fish as exemplified by tilapia: applications, problems, and prospects. Aquaculture 197:283-301

Blazquez M, Zanuy S, Carrillo M, Piferrer F (1998) Structural and functional effects of early exposure to estradiol-17b and 17a-ethynylestradiol on the gonads of the gonochoristic teleost Dicentrarchus labrax. Fish Physiol Biochem 18:37-47

Cakmak G, Togan I, Severcan F (2006) 17 $\beta$-Estradiol induced compositional, structural and functional changes in rainbow trout liver, revealed by FT-IR spectroscopy: a comparative study with nonylphenol. Aquat Toxicol 77:53-63

Cardenas R, Lin X, Canosa LF, Luna M, Aramburo C, Peter RE (2003) Estradiol reduces pituitary responsiveness to somatostatin (SRIF-14) and down-regulates the expression of somatostatin sst2 receptors in female goldfish pituitary. Gen Comp Endocrinol 132:119-124

Cowey CB, Pope JA, Adron JW, Blair A (1973) Studies on the nutrition of marine flatfish: the effect of oral administration of diethylstilbestrol and cyproheptadine on growth of Pleuronectes platessa. Mar Biol 19:1-6

Davies BK, Ludwig GM (2003) Hormonal effects on sex differentiation and growth in sunshine bass Morone chrysops x Morone saxatilis. Aquaculture 231:587-596

Fauconneau B, Laroche M (1996) Characteristics of the flesh and quality of products of catfishes. Aquat Living Resour 9:165-179

Flynn SR, Benfey TJ (2007) Effects of dietary estradiol-17 $\beta$ in juvenile shortnose sturgeon, Acipenser brevirostrum, Lesueur. Aquaculture 270:405-412

Gannam AL, Lovell RT (1991) Effects of feeding 17 $\alpha$-methyltestosterone, 11-ketotestosterone, 17 $\beta$ estradiol, and 3,5,3 V-triiodothyronine to channel catfish, Ictalurus punctatus. Aquaculture 92: 377-388

George T, Pandian TJ (1996) Hormonal induction of sex reversal and progeny testing in the zebra cichlid Cichlasoma nigrofasciatum. J Exp Zool 275:374-382

Haffray P, Vauchez C, Vandeputte M, Linhart O (1998) Different growth and processing traits in males and females of European catfish Silurus glanis. Aquat Living Resour 11(5):341-345

Haniffa MA, Sridhar S, Nagarajan M (2004) Hormonal manipulation of sex in stinging catfish Heteropneustes fossilis (Bloch). Current Sci 86(7):1012-1017

Hassan HA, Enright WJ, Tucker AH, Merkel RA (2001) Estrogen and androgen elicit growth release via dissimilar patterns of hypothalamic neuropeptide secretion. Steroids 66:71-80 
Haux C, Norberg B (1985) The influence of estradiol-17 $\beta$ on the liver content protein, lipids, glycogen and nucleic acids in juvenile rainbow trout. Comp Biochem Physiol 72:165-172

Hendry ChI, Deborah J, Martin-Robichaud JD, Benfley JT (2003) Hormonal sex reversal of Atlantic halibut (Hippoglossus hippoglossus L.). Aquaculture 219:769-781

Hliwa P, Demska-Zakęś K, Martyniak A, Król J (2003) Gonadal differentiation in Vimba vimba (L. 1758). Czech. J Anim Sci 48(11):441-448

Hopkins KD, Shelton WL, Engle CR (1979) Estrogen sex reversal of Tilapia aurea. Aquaculture 18:263-268

Hossain Z, Rahman MM, Afruj S (2002) Effects of different level of estradiol $17 \beta$ on growth, survival and sex-ratio of African catfish (Clarias gariepinus, Burchell). Pak J Biol Sci 5(3):355-358

Hunter GA, Solar II, Baker IJ, Donaldson EM (1986) Feminization of coho salmon Oncorhynchus kisutch and chinook salmon Oncorhynchus tshawytscha. by immersion of alevins in a solution of estradiol-17 $\beta$. Aquaculture 53:295-302

Johnstone R, Simpson TH, Walker AF (1979) Sex reversal in salmonid culture: part III. The production and performance of all-female populations of brook trout. Aquaculture 18:241-252

Kavumpurath S, Pandian TJ (1993) Determination of labile period and critical dose for sex reversal by oral administration of estrogens in Betta splendens (Regan). Ind J Exp Biol 31:16-26

Kim DS, Nam YK, Jo JY (1997) Effect of oestradiol-17ß immersion treatments on sex reversal of mud loach, Misgurnus mizolepis. Aquac Res 28:941-946

Linhart O, Stech L, Svarc J, Rodina M, Audebert JP, Grecu J, Billard R (2002) The culture of the European catfish, Silurus glanis L. in Czech Republic and in France. Aquat Living Resour 15:139-144

Malison JA, Kayes TB, Wentworth BC, Amundson CH (1988) Growth and feeding response of male versus female yellow perch (Perca flavescens) treated with estradiol-17 $\beta$. Can J Fish Aquat Sci 45:1942-1948

Matty AJ, Cheema IR (1978) The effect of some steroid hormones on the growth and protein metabolism of rainbow trout. Aquaculture 14:163-178

Pandian TJ, Sheela SG (1995) Hormonal induction of sex reversal in fish. Aquaculture 138:1-22

Piferrer F (2001) Endocrine sex control strategies for the feminization of teleost fish. Aquaculture 197:229-281

Rosenstain S, Hulata G (1994) Sex reversal in the genus Oreochromis: optimization of feminization protocol. Aquac Fish Manag 26:329-339

Schulz RW, de Franca LR, Lareyre JJ, Le Gac F, Chiarini-Garcia H, Nobrega RH, Miura T (2010) Spermatogenesis in fish. Gen Comp Endocrinol 165:390-411

Shved N, Berishvili G, D'Cotta H, Baroiller JF, Segner H, Eppler E, Reinecke M (2007) Ethinylestradiol differentially interferes with IGF-I in liver and extrahepatic sites during development of male and female bony fish. J Endocrinol 195:513-523

Tzchori I, Degani D, Elisha R, Eliyahu R, Hurwitz A, Vaya J, Moav B (2004) The influence of phytoestrogens and oestradiol-17 $\beta$ on growth and sex determination in the European eel (Anguilla anguilla). Aquac Res 35:1213-1219

van Bohemen CG, Lambert JGD, Goos HJT, van Oordt PGWJ (1982) Estrone and estradiol participation during exogenous vitellogenesis in the female rainbow trout (Salmo gairdneri). Gen Comp Endocrinol 46:81-92

Verslycke T, Vandenbergh GF, Versonnen B, Arijs K, Janssen CR (2002) Induction of vitellogenesis in 17-ethinylestradiol-exposed rainbow trout (Oncorhynchus mykiss): a method comparison. Comp Biochem Physiol 132C:483-492

Washburn BS, Krantz JS, Avery EH, Freedland RA (1993) Effects of estrogen on gluconeogenesis and related parameters in male rainbow trout. Am J Physiol 264:720-725

Yang L, Lin L, Weng S, Feng Z, Luan T (2008) Sexually disrupting effects of nonylphenol and diethylstilbestrol on male silver carp (Carassius auratus) in aquatic microcosms. Ecotoxicol Environ Saf 71:400-411 